\title{
Diego Romero Heredero Telicity and Differential Object Marking in the history of Spanish
}

\begin{abstract}
This paper explores the influence of telicity on Differential Object Marking (DOM) from a diachronic perspective. Previous research has frequently pointed to telicity as one of the verbal factors that trigger DOM in Spanish. However, this assumption has not been tested empirically. The present study provides a corpus analysis examining the question of whether the assumed impact of telicity on DOM in Modern Spanish, which has been observed in synchronic studies, also holds for earlier stages of Spanish. The corpus-based study covers the $14^{\text {th }}, 16^{\text {th }}$ and $20^{\text {th }}$ centuries, and is the first empirical study that addresses the relationship between telicity and DOM with human direct objects. The results challenge previous analyses, suggesting that telicity has no significant impact on DOM in the periods surveyed. These findings lead us to conclude that telicity alone does not trigger DOM, which raises the question of whether it is possible that the effect of telicity observed in previous studies could be the consequence of the interaction of telicity with other verbal factors such as affectedness or agentivity.
\end{abstract}

Keywords: aspectual class, corpus analysis, definiteness, Differential Object Marking (DOM), language change, lexical aspect, telicity, verbal factors

\footnotetext{
Acknowledgements: This paper was presented at the Workshop "Differential Object Marking in Spanish - diachronic change and synchronic variation" (University of Zurich, Zurich, June $4^{\text {th }}-5^{\text {th }}$, 2018). I would like to thank the organizers of the workshop, Larissa Binder, Johannes Kabatek, Philipp Obrist and Albert Wall, for the great space for discussion they gave me, and the audience of the workshop for their comments. I would also like to thank Javier Caro Reina, Marco García García, Klaus von Heusinger and Manuel Leonetti for their comments and invaluable support, without which this article would certainly not have been possible. The research for this paper has been funded by the Deutsche Forschungsgemeinschaft (DFG - German Research Foundation) SFB 1252 (Project-ID 281511265) Prominence in language within the project B04, Interaction of nominal and verbal features for Differential Object Marking, at the University of Cologne.
}

Diego Romero Heredero University of Cologne, e-mail: d.romeroheredero@uni-koeln.de 


\section{Introduction}

Differential Object Marking (DOM) is a grammatical phenomenon conditioned by the interaction of various factors (cf. García García 2018 for an overview). These factors are not only related to the noun phrase (NP) having the function of direct object, but also to other aspects of the context in which it appears. In the early 1950s, Fernández Ramírez had already pointed out with regard to Spanish that "the nature of the verb and the nature of the noun or pronoun that functions as a direct object influence this phenomenon" (1951, 151). In this regard, Laca (2006) distinguishes between local and global factors. Local factors are those concerned with the properties of the NP that occupies the object position, while global factors are those concerned with the context in which it appears (Laca 2006, 430-431). More precisely, the animacy of the direct object, its degree of referentiality and the specificity of the referent are considered local factors (Company Company 2002; Leonetti 2004; Laca 2006). On the other hand, global factors are those related to the semantics of the verb, such as telicity, affectedness and agentivity (Torrego 1998; 1999; von Heusinger 2008; 2011; García García 2014; Romero Heredero in press); the presence of secondary predication referring to the object (Laca 2006); the topicality of the object and clitic doubling (Melis 1995; Torrego 1998; Laca 2006; Ormazábal/Romero 2013).

The influence of local factors has been widely documented in Spanish, not only from a synchronic point of view, but also from a diachronic perspective (Company Company 2002; Laca 2006; von Heusinger 2008). In contrast, global factors, and more specifically those related to the lexical properties of the verb, have not received as much attention. Nevertheless, while some studies deal with affectedness and agentivity, establishing the extent to which these factors influence DOM (Pottier 1968; von Heusinger 2008; 2011; García García 2018), telicity continues unattended, with the exception of the work of Torrego $(1998 ; 1999)$, which will be presented in Section 2 .

The aim of this paper is to shed light on the factor of telicity drawing on diachronic data. It will be discussed whether telicity has been a trigger for DOM in earlier stages of Spanish, as assumed for Modern Spanish, and whether the diachronic evolution of DOM supports the claims about the effect of telicity at present. Thus, the impact of telicity on DOM with human direct objects is addressed for the first time from a diachronic perspective and with an empirical methodology. ${ }^{1}$

The paper is structured as follows: Section 2 deals with the relationship between lexical aspect and case marking, which has been studied in many lan-

1 For a more detailed version of the analysis that also includes affectedness and the interaction between telicity and affectedness, cf. Romero Heredero (in press). 
guages and, more specifically, addresses the effect of telicity on DOM which has been suggested for Spanish by previous studies; Section 3 presents the diachronic corpus study conducted for the $14^{\text {th }}, 16^{\text {th }}$ and $20^{\text {th }}$ centuries; finally, Section 4 summarizes all the findings derived from the corpus study and the most important ideas raised in the discussion about the influence of telicity on DOM.

\section{Telicity, case-marking and DOM}

Telicity is a property of the verbal phrase (VP) implying the existence of an end point, after which the event designated by the predicate terminates or does not continue to take place (Verkuyl 1972; Dowty 1979; Tenny 1994; Krifka 1998). Hopper and Thomson $(1980,252)$ point to telicity as one of the factors linked to a high degree of transitivity in the clause, arguing that an action described by a telic VP is more effectively transferred to the object than one lacking an endpoint.

The relationship between case-marking and telicity or, more broadly, between case-marking and aspect, is a phenomenon that is well documented in many languages (Richardson 2012, 965). This relationship has been suggested for Slavic languages (Russian, Borer 2005, among others; Belarusian, Ukrainian, Czech, Slovak, Polish, Bosnian/Croatian/Serbian, Richardson 2007), Germanic languages (German, Leiss 2000, among others; Icelandic, Svenonius 2002), and even more prominently, for Finno-Ugric languages (Finnish, Kiparsky 1998, among others; Estonian, Tamm 2007, among others; Hungarian, Csirmaz 2006). Although, to a lesser extent, the case-aspect relationship has also been defended for other languages such as Scottish Gaelic (Ramchand 1997), Hindi (Mohanan 1984) or Spanish (Torrego 1998; 1999), among others.

One of the most frequently cited languages that exhibits this case-aspect relationship is Finnish, which presents an accusative-versus-partitive opposition for the internal argument which seems to be linked to an aspectual contrast (Richardson 2012, 965). The nature of that opposition has been described in terms of boundedness, telicity, and sometimes both. Kiparsky's examples in (1) exemplify this relationship. In Finnish the accusative has been characterized in terms of resultativity, as illustrated in (1) by the verb to shoot. This verb can assign different cases, giving rise to different aspectual interpretations. While in (1a) the verb has a partitive object and denotes an activity ('to shoot at'), in (1b) the verb is followed by an accusative object and describes an accomplishment ('to shoot dead') (Kiparsky 1998, 266-267). This example shows that accusative case in Finnish is associated with a telic character of the event, while partitive case is related to an atelic reading. 
(1) Case-marking in Finnish
shoot-PST-1SG bear-PART
'I shot at the/a bear.'
a. Ammu-i-n karhu- $a$
b. Ammu-i-n karhu-n shoot-PST-1SG bear-ACC 'I shot the/a bear.'

(Kiparsky 1998, 266-267)

With regard to Spanish, Torrego $(1998 ; 1999)$ are the only studies devoted to the interaction between DOM and lexical aspect. Torrego (1999) describes the relationship between DOM and telicity ${ }^{2}$ according to the assumptions in (2).

(2) Interaction between telicity and DOM in Spanish

a. Telic verbs impose DOM on their direct object.

b. DOM triggers a telic interpretation on atelic verbs.

(Torrego 1999, 1787-1790)

The first assumption (2a) refers to the requirement of DOM by telic verbs. Following Torrego, telic verbs, which comprise achievements (e.g. encontrar 'to find') and accomplishments (e.g. construir 'to build'), describe delimited situations, and this delimitation confers them a specific character. The direct object of telic verbs moves to a certain syntactic position which implies the interpretation of the $\mathrm{NP}$ as the boundary of the event and, therefore, as specific. In that position the object receives a certain type of case that implies $a$-marking in Spanish. Therefore, telic verbs require DOM due to the specific character of the situations they describe and, for this reason, intrinsically telic verbs, such as insultar 'to insult', obligatorily require their direct object to be marked with DOM, as can be observed in (3), where the sentence without $a$-marking would be ungrammatical.

(3) DOM with telic verbs

Marta insultó * (a) un compañero.

'Marta insulted a colleague.'

(Torrego 1999, 1787)

The second assumption (2b) is aimed at the interpretation of atelic verbs. In contrast to telic verbs, these verbs do not require DOM. However, their interpreta-

2 Torrego refers to the inherent telicity of certain aspectual classes of verbs, not to telicity as a property of the VP. 
tion changes if the direct object is differentially $a$-marked. Following Torrego, $a$-marking forces a reading of the object as specific and this implies a telic reading of the event. The example in (4a) shows that activity verbs, such as besar 'to kiss', do not require DOM. Nevertheless, the reading is telic when the direct object is $a$-marked, as can be observed in (4b), where the verb admits a temporal prepositional phrase (PP) introduced by the preposition en 'in' (telicity test). This reading is not obtained in (4c), where the temporal PP is rejected.

(4) DOM with atelic verbs
a. Besaron (a) un niño.
b. Besaron a un niño en un segundo.
c. *Besaron un niño en un segundo.
'They kissed a boy (in a second).'

(Torrego 1999, 1788-1789)

The two assumptions presented above represent the only systematic attempt so far to describe the impact of telicity on DOM in Spanish. However, they are based on a rather small number of examples and subsequent studies have suggested that speakers' intuitions do not always support them (Delbecque 2002, 90; Fábregas 2013, 25). Furthermore, it should be noted that these assumptions have not been empirically tested. Moreover, they only address the issue from a synchronic perspective.

The following section provides a diachronic corpus analysis investigating the impact of telicity on DOM from $14^{\text {th }}$ to $20^{\text {th }}$-century European Spanish.

\section{Diachronic corpus analysis}

In order to study the effect of telicity on DOM in the $14^{\text {th }}, 16^{\text {th }}$ and $20^{\text {th }}$ centuries, I conducted a corpus analysis based on the Corpus del Diccionario histórico de la lengua española (CDH). Section 3.1 presents the hypotheses according to the assumptions of the previous studies described in Section 2. Section 3.2 is dedicated to the design of the study. Section 3.3 contains the results according to definiteness, telicity and aspectual class of the verbs. Finally, Section 3.4 discusses the results. 


\subsection{Hypothesis}

As mentioned in Section 1, some diachronic studies on factors such as referentiality or affectedness have shown that their impact on DOM was already present in previous stages of Spanish. However, telicity has been studied only from a synchronic perspective so far. This leads to the question of whether this factor also had any impact on previous stages of Spanish. To address this question, I have conducted a corpus study encompassing the $14^{\text {th }}, 16^{\text {th }}$ and $20^{\text {th }}$ centuries with the hypothesis reported in (5).

(5) Hypothesis for DOM and telicity

The occurrence of DOM is more frequent with human direct objects of telic predicates than with human direct objects of atelic predicates.

This hypothesis is based on the notion of telicity as a property of the VP, as introduced in Section 2. This remark is relevant since previous studies that have addressed the relationship between telicity and DOM have generally based their hypotheses on a more restricted concept of telicity that refers only to the semantics of the verb (inherent telicity). The problem with this approach arises when categorizing certain verbs according to their inherent telicity in terms of Vendler (1957) (cf. Marín 1999 for discussion). In (6) the verb to run can be considered either atelic (activity verb) or telic (accomplishment verb) depending on the argument structure it exhibits.

(6) To run with different argument structure

a. Mary runs. (one argument; activity)

b. Mary runs a mile. (two arguments; accomplishment)

Considering this problem, it seems safer to take the definition of telicity as a property of the VP, and to classify all the VPs according to their behaviour in the test that has traditionally been used to distinguish telic from atelic predicates. As can be seen in (7), those VPs that admit a PP headed by the preposition in with a delimiting function will be considered telic, while those that do not admit it will be classified as atelic.

(7) Telicity test

a. ${ }^{\star}$ Mary runs in an hour.

b. Mary runs a mile in an hour. 


\subsection{Study design}

The analysis is based on the Corpus del Diccionario historico de la lengua española $(\mathrm{CDH})$. It comprises the entries corresponding to the $\mathrm{CDH}$ nuclear as well as a selection of texts from both the Corpus diacrónico del español (CORDE) and the Corpus de referencia del español actual (CREA). The CDH allows for the search of single words (or a combination of words) according to word class, author, work, time span, text type, country and text subject. Unfortunately, this corpus is only partially annotated and, although it allows searching by word type, it is not possible to search for specific syntactic patterns such as DOM.

The search is restricted to European Spanish of the $14^{\text {th }}, 16^{\text {th }}$ and $20^{\text {th }}$ centuries. The sources for European Spanish are extensive enough for a diachronic study since they contain a total of 7,745,250 words for the $14^{\text {th }}$ century, $49,797,748$ words for the $16^{\text {th }}$ century and $113,509,174$ words for the $20^{\text {th }}$ century. The time span selection is motivated by Octavio de Toledo's (2016, 61-64) observation that the $18^{\text {th }}$ and $19^{\text {th }}$ centuries are less represented than the rest of the periods in the CORDE and, consequently, in the CDH. Moreover, the same author argues that these centuries constitute a period of great linguistic variation contrary to what had been previously defended (cf. Kabatek 2016 for discussion). With this in mind, it has been decided to avoid them and to select three periods whose representation in the corpus is wider and which present more internal stability.

The study is based on 3,200 instances following a 2x2x3 factorial design that takes into account telicity, definiteness and century as independent variables, and the presence/absence of DOM as dependent variable. The distribution of instances according to the independent variables has been structured as follows (cf. Table 1): as far as telicity is concerned, half of the instances contain a telic VP and the other half show an atelic VP. With regard to definiteness, $75 \%$ of the cases have a definite direct object NP and the remaining 25\% contain an indefinite direct object NP. Finally, regarding the temporal distribution, the $14^{\text {th }}$ century represents $20 \%$ of instances; the $16^{\text {th }}$ century $30 \%$; and the $20^{\text {th }}$ century $50 \%$. This configuration allows an easy comparison between the results obtained for telic and atelic VPs, being this the main goal of the study, since both categories are equally represented. As regards the distribution of cases according to definiteness and century, the configuration reflects the availability of instances found in the corpus for the different categories.

All instances extracted from the corpus to complete the distribution described above contain a full definite or indefinite human direct object NP in postverbal position (SVO). Thus, collective nouns, animate non-human NPs, inanimate NPs, proper names, bare nouns and left dislocations are excluded. 
Table 1: Distribution of instances extracted from the CDH according to century, telicity and definiteness.

\begin{tabular}{llrrrr}
\hline & & $\mathbf{1 4}^{\text {th }}$ century & $\mathbf{1 6}^{\text {th }}$ century & $\mathbf{2 0}^{\text {th }}$ century & TOTAL \\
\hline [+ telic] & definite NP & 240 & 360 & 600 & 1,200 \\
\cline { 2 - 6 } & indefinite NP & 80 & 120 & 200 & 400 \\
\hline [- telic] & definite NP & 240 & 360 & 600 & 1,200 \\
\cline { 2 - 6 } & indefinite NP & 80 & 120 & 200 & 400 \\
\hline & TOTAL & 640 & 960 & 1,600 & 3,200 \\
\hline
\end{tabular}

The collection of the 3,200 examples is based on the selection of ten inherently telic verbs and ten atelic verbs, following Vendler's classification. This selection has not implied the assignment of the instances of each verb to a certain category, but it has been just the starting point, since the telicity of each case has been evaluated individually using the test described in Section 3.1. Then, the search for instances has been carried out, starting from those verbs, until achieving the pre-established quantity of instances for each category. ${ }^{3}$ When the first ten verbs have not been enough to reach this goal, other verbs that meet the necessary conditions have been added (cf. Appendix for a complete list of the verbs used for the analysis). Possible changes in meaning or argument structure of the verbs over time have been taken into account using the Diccionario del castellano del siglo XV en la Corona de Aragón (DiCCA-XV). Further, it has been checked that the contribution of examples of each verb amounts to a maximum of $10 \%$, thus ensuring that each category is comprised of at least 10 verbs. This measure avoids a situation where the result corresponding to each category reflects the behaviour of single verbs that have higher representation in the corpus.

Having obtained all the examples, they have been described individually according to the presence or absence of DOM (dependent variable) and the aspectual class of the verb (inherent telicity). With regard to the latter, it has been annotated according to the most common argument structure of each verb, taking into account the potential problems this may entail (cf. Section 3.1). However, this information may be interesting to check the assumptions of previous studies.

3 The concept of "category" in this context refers to the different sets of examples that are generated by the factorial design of the search, e.g. definite direct objects in telic VPs from the $16^{\text {th }}$ century. 


\subsection{Results}

This section describes the results of the corpus-based study according to definiteness, telicity and aspectual class. The results are presented in five different figures which allow us to observe the evolution of the impact on DOM of the different factors.

The first part of this section is devoted to definiteness. Although the hypothesis of this work does not directly refer to this factor, definiteness is essential in order to understand the evolution of DOM in Spanish. In addition, another reason for including the results of definiteness here is to provide an overview of the evolution of DOM which allows us to check whether this data points in the same direction as the results obtained in previous studies. Figure 1 illustrates the occurrence of DOM according to century $\left(14^{\text {th }} / 16^{\text {th }} / 20^{\text {th }}\right)$ and definiteness (definite $\mathrm{NP} /$ indefinite NP). With regard to indefinite direct object NPs, the presence of DOM shows a relative frequency of $28 \%$ (44/160) in the $14^{\text {th }}$ century, 35\% (85/240) in the $16^{\text {th }}$ century and $70 \%(279 / 400)$ in the $20^{\text {th }}$ century. As far as definite direct object NPs are concerned, the occurrence of DOM has a relative frequency of $50 \%(242 / 480)$ in the $14^{\text {th }}$ century, 65\% (468/720) in the $16^{\text {th }}$ century and $93 \%$ $(1120 / 1200)$ in the $20^{\text {th }}$ century. Although there has been a general increase in the presence of DOM over time, this data shows that definite human direct object NPs have always favoured the presence of DOM over indefinite human direct object NPs.

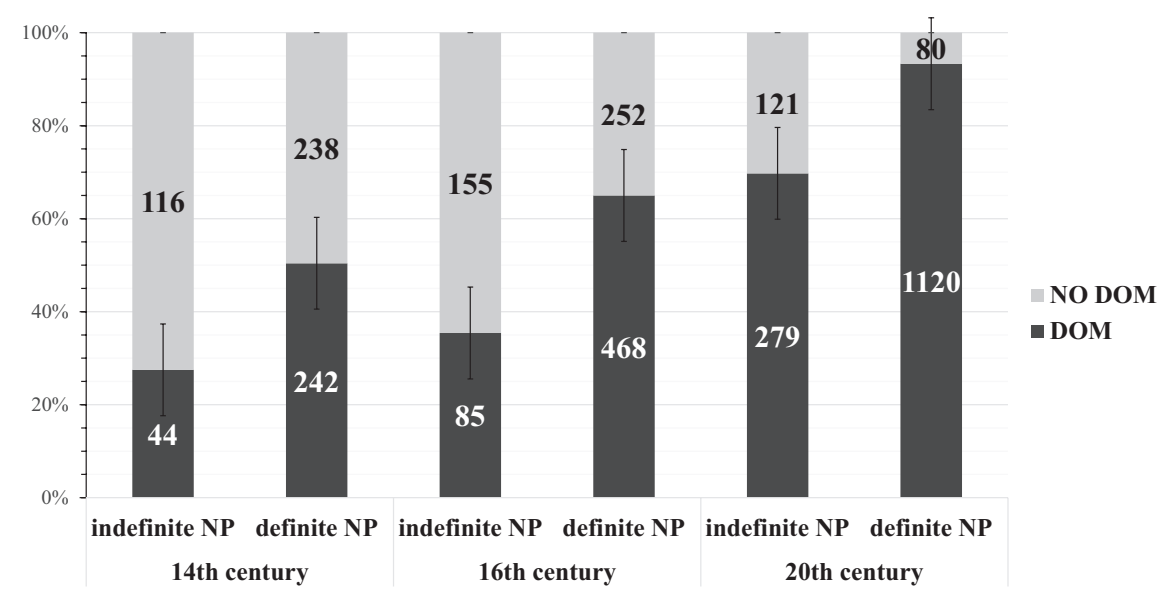

Figure 1: DOM according to century and definiteness. 
Note also that these numbers largely confirm the results obtained in previous diachronic corpus-based studies (Company Company 2002; Laca 2006; von Heusinger/Kaiser 2011).

Figures 2 and 3 present the results for telicity according to definite and indefinite NPs, respectively. In the case of definite NPs, the relative frequency of DOM with regard to telicity is distributed as follows: the occurrence of DOM shows a relative frequency of 54\% (129/240) with atelic predicates and 47\% (113/240) with telic predicates in the $14^{\text {th }}$ century. In the $16^{\text {th }}$ century, the use of DOM registers a relative frequency of $66 \%$ (237/360) for atelic predicates and 64\% (231/360) for telic predicates. Finally, the presence of DOM has a relative frequency of $95 \%$ (568/600) for atelic predicates and 92\% (552/600) for telic predicates in the $20^{\text {th }}$ century. The occurrence of DOM increases over time as shown in the results according to definiteness. However, Figure 2 does not show any significant effect of telicity on DOM with definite direct objects in any of the three periods.

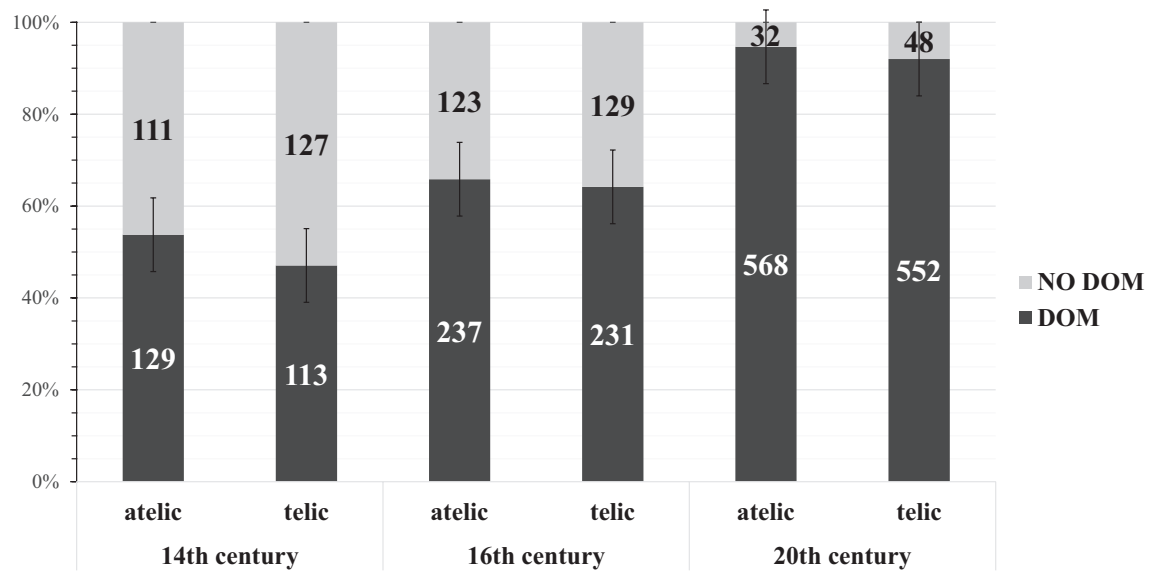

Figure 2: DOM with definite NPs according to century and telicity.

Examples of the lack of DOM from $20^{\text {th }}$-century Spanish with definite human direct objects are given in (8), where both a direct object of an atelic VP, such as recordar la hortelana 'to remember the gardener', and a direct object of a telic VP, such as abatir sus caciques 'to overthrow their chiefs' are not differentially marked. 
(8) Definite NPs without DOM in $20^{\text {th }}$-century Spanish

a. ¿Recuerda usted la pobre hortelana enferma que vimos en la ermita aquella tarde? (atelic predicate)

'Do you remember the poor sick gardener we saw at the hermitage that afternoon?'

(20 ${ }^{\text {th }}$ century, Blasco Ibáñez, Entre naranjos)

b. La civilización que [...] abatió sus caciques. (telic predicate)

'The civilization that [...] overthrew their chiefs.'

$\left(20^{\text {th }}\right.$ century, Lopetegui/Zubillaga, Historia de la Iglesia en la América española desde el descubrimiento hasta el siglo XIX)

Turning to indefinite NPs, i.e. to Figure 3, the relative frequency of DOM is distributed as follows: the occurrence of DOM has a relative frequency of $35 \%$ (28/80) with atelic predicates and $20 \%(16 / 80)$ with telic predicates in the $14^{\text {th }}$ century. In the $16^{\text {th }}$ century, the use of DOM registers a relative frequency of $41 \%$ (49/120) for atelic predicates and 30\% (36/120) for telic predicates. Finally, the presence of DOM shows a relative frequency of 69\% (137/200) for atelic predicates and $71 \%$ (142/200) for telic predicates in the $20^{\text {th }}$ century. As was observed in the case of definite direct objects, we can see the increase in the relative frequency of DOM with indefinite direct objects over time. Furthermore, in the case of indefinite NPs, the $14^{\text {th }}$ and $16^{\text {th }}$ centuries show a slight tendency to favour the occurrence of DOM in atelic VPs, however the effect is not significant. Consequently, the assumed hypothesis of the influence of telicity on DOM could not be confirmed.

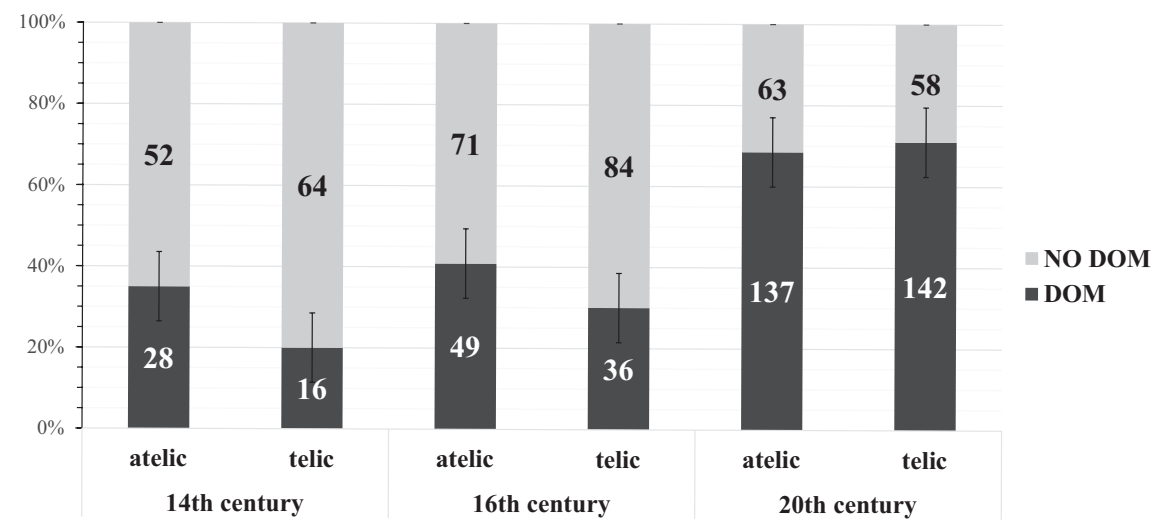

Figure 3: DOM with indefinite NPs according to century and telicity. 
Examples of the presence of DOM from $14^{\text {th }}$-century Spanish with indefinite human direct objects are given in (9), where all examples present $a$-marking in their direct object regardless of whether the predicate is telic or atelic.

(9) Indefinite NPs with DOM in $14^{\text {th }}$-century Spanish

a. Juan Núñez amava a un cavallero que desían Gonçalo Gómez. (atelic predicate)

'Juan Núñez loved a knight who was called Gonçalo Gómez.'

(14 ${ }^{\text {th }}$ century, Anonymous, Crónica del muy valeroso rey don Fernando el cuarto)

b. En la manyana ella encontro a vn ciudadano antigo. (telic predicate) 'In the morning she found an old citizen.'

(14 ${ }^{\text {th }}$ century, Fernández de Heredia, Traducción de Vidas paralelas de Plutarco, III)

Figures 4 and 5 summarize the results for aspectual class according to definite and indefinite NPs, respectively. It is important to remember that the number of instances contained in each category is not balanced in this case since aspectual class is only addressed indirectly in this study. With regard to definite NPs, the relative frequency of DOM is distributed as follows: the occurrence of DOM presents in the $14^{\text {th }}$ century a relative frequency of $61 \%$ (43/70) with states, $49 \%$ (86/176) with activities, 44\% (28/64) with accomplishments and 50\% (85/170) with achievements. In the $16^{\text {th }}$ century, the use of DOM exhibits a relative frequency of $64 \%$ (63/98) for states, 65\% (179/277) for activities, 60\% (61/102) for accomplishments and 68\% (165/243) for achievements. Lastly, the presence of DOM registers a relative frequency of $90 \%$ (150/166) with states, 96\% (452/472) with activities, 93\% (125/134) with accomplishments and 92\% (393/428) with achievements in the $20^{\text {th }}$ century. Although the increase in DOM over time is again visible in Figure 4, the aspectual class shows no significant effect on the occurrence of $a$-marking with definite objects.

Examples of the lack of DOM from $20^{\text {th }}$-century Spanish with definite human direct objects are given in (10), where both the direct object of an activity verb, such as guiar 'to guide', and the direct object of an achievement verb, such as hallar 'to find', are not differentially marked. 


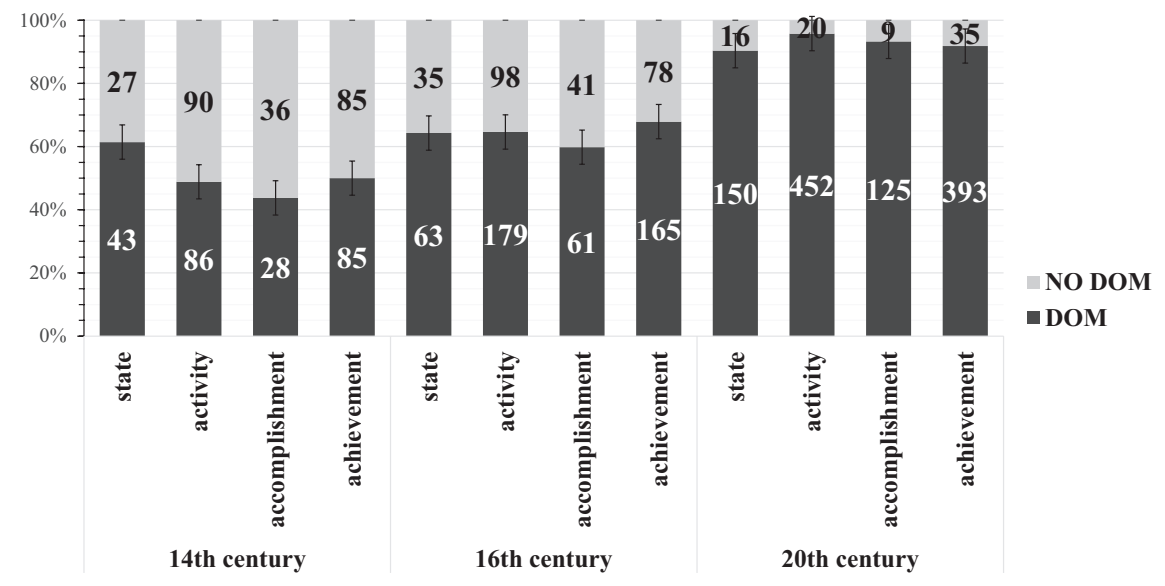

Figure 4: DOM with definite NPs according to century and aspectual class.

(10) Definite NPs without DOM in $20^{\text {th }}$-century Spanish

a. Y guiaré los ciegos por camino que no sabían. (activity)

'And I will lead the blind by a way which they did not know.'

( $20^{\text {th }}$ century, Anonymous, Biblia Reina-Valera)

b. entre pescadores halló Cristo sus primeros secuaces. (achievement)

'Among fishermen, Christ found his first followers.'

( $20^{\text {th }}$ century, Pardo Bazán, San Francisco de Asís. Siglo XIII)

Turning to indefinite NPs, Figure 5 shows the following distribution: the presence of DOM in the $14^{\text {th }}$ century has a relative frequency of $23 \%(5 / 22)$ for states, $40 \%$ (23/58) for activities, 9\% (1/11) for accomplishments and 22\% (15/69) for of achievements. In the $16^{\text {th }}$ century, DOM registers a relative frequency of $20 \%(7 / 35)$ for states, 50\% (43/86) for activities, 33\% (12/36) for accomplishments and 28\% (23/83) for achievements. Finally, DOM shows a relative frequency of $40 \%(23 / 58)$ for states, 82\% (122/149) for activities, 86\% (31/36) for accomplishments and 66\% $(103 / 157)$ for achievements in the $20^{\text {th }}$ century. Like in the rest of the figures, an increase of DOM can be observed in relation to the different periods. Moreover, while the variation between aspectual classes is almost imperceptible in Figure 4 , in the case of indefinite NPs a higher variation can be noticed. However, the differences between aspectual classes have turned out not to be significant. Thus, the data presented in this paper cannot confirm the relationship between inherently telic verbs and DOM proposed in previous studies. 


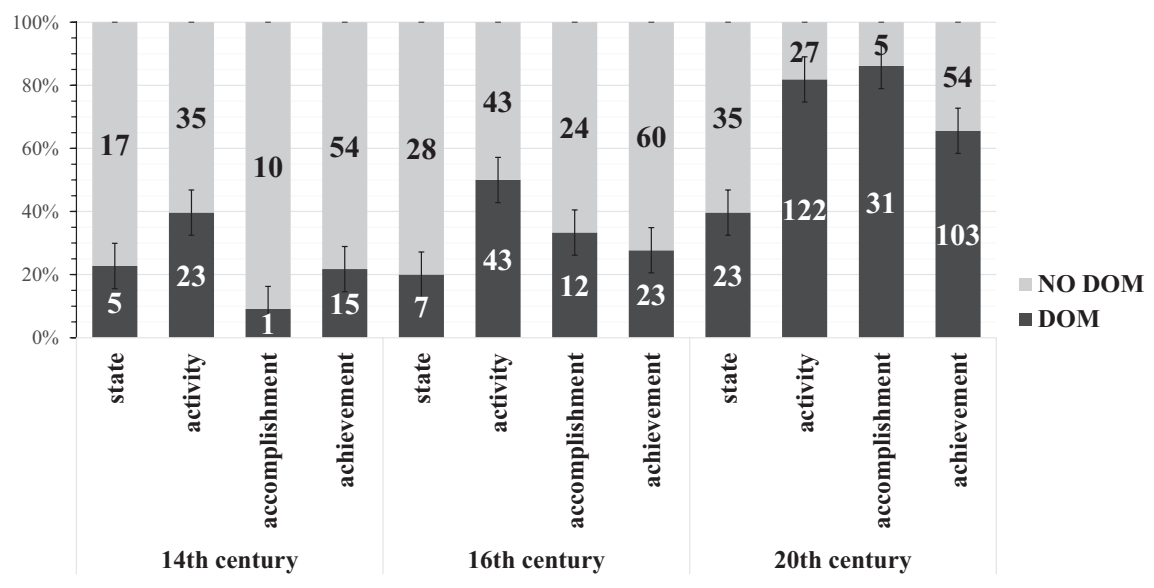

Figure 5: DOM with indefinite NPs according to century and aspectual class.

Examples of the presence of DOM from $14^{\text {th }}$-century Spanish with indefinite human direct objects are given in (11), where both present $a$-marking in their direct object regardless of aspectual class.

(11) Indefinite NPs with DOM in $14^{\text {th }}$-century Spanish

a. non guardauan a otras mugeres sinon a sus madres. (activity)

'They did not respect other women apart from their mothers.'

(14 ${ }^{\text {th }}$ century, Don Juan Manuel, Libro de los estados)

b. et clamo a vn cauallero que era aguazil suyo. (achievement)

'And he called a knight who was his sheriff.'

(14 ${ }^{\text {th }}$ century, Fernández de Heredia, Gran crónica de España III)

\subsection{Discussion}

The results of the corpus-based study presented in the previous section do not confirm the hypothesis proposed in Section 3.1 repeated herein (12).

(12) Hypothesis for DOM and telicity

The presence of DOM is more frequent with human direct objects of telic predicates than with human direct objects of atelic predicates.

The corpus analysis has revealed that telicity had no impact on the presence of DOM in previous centuries. Similarly, aspectual class does not show any clear relationship with the use of $a$-marking. These results question Torrego's (1999, 
1787) first assumption (cf. 2a), since the inherent telicity of accomplishments and achievements neither implies DOM in the $20^{\text {th }}$ century, nor triggers its occurrence in previous stages of Spanish.

However, it is interesting to note that with indefinite direct objects a slight variation can be observed which does not exist for definite direct objects. This can be seen in the results concerning both telicity and aspectual class. Although these are not significant differences, it means that telicity or aspectual class might have a slight effect on DOM, perhaps as a consequence of its interaction with other factors, but only on indefinite direct objects. Therefore, if such a slight variation can be explained by the interaction of telicity with some other factor, the effect of telicity is subordinated to definiteness and does not act directly on direct human objects, contrary to what previous studies defended.

Although this study is the only diachronic empirical study that addresses the impact of telicity on DOM for human direct objects, indirect evidence supporting the results presented above can be found in Barraza (2008), which deals with the relationship between DOM and telicity for inanimate direct objects. It is important to note that her concept of telicity refers to the aspectual class of verbs and not to the whole VP. Thus, she groups under the category of "telic" those instances which contain accomplishment and achievement verbs, and brings together under the label of "atelic" those whose verb is a state or an activity. Her study is based on a corpus comprised of 2,260 instances of inanimate direct objects which fall into three different periods $\left(15^{\text {th }}-16^{\text {th }}\right.$ centuries, $18^{\text {th }}$ century and $20^{\text {th }}$ century). The results obtained from her corpus analysis are shown in Figure 6. Interestingly, they point in the same direction as the results of the study I have carried out. Following Barraza, telicity does not have a relevant impact on DOM with inanimate direct objects. However, a minimal effect can be observed that favours the occurrence of DOM with inherently atelic verbs in previous stages of Spanish. This pattern matches the slight tendency that has been described above for indefinite direct objects in this study.

It is also interesting to comment on some aspects related to Torrego's second assumption (2b), which holds that DOM triggers a telic interpretation in atelic verbs (1999, 1788-1790). I should start by pointing out the difficulty of addressing this issue with a corpus-based study, since it is necessary to have adverbials that explicitly reflect the aspectual reading of the verb. However, the example in (13a) allows us to address this issue, as it contains an activity verb, maltratar 'to abuse', with an adverbial that reinforces the atelic reading. Even so, following Torrego, it could be argued that, since the object is marked, the reading of the predicate is telic and that the PP headed by durante 'for' leads to an iterative reading of the telic event. However, in (13b) we observe that if the PP indicating duration is replaced by another PP that delimits the event, the result is ungrammatical. This indicates 


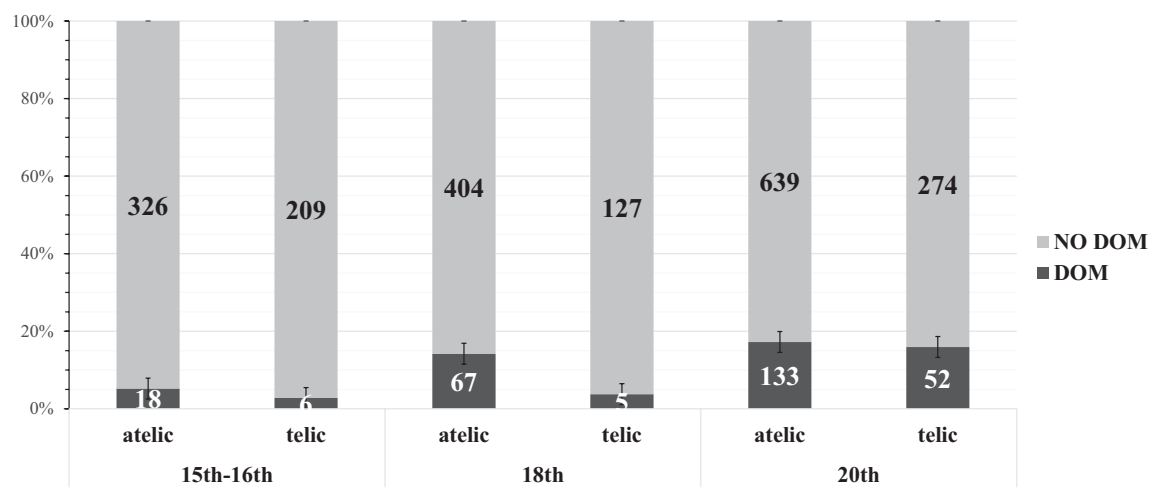

Figure 6: DOM with inanimate NPs according to century and telicity (adapted from Barraza 2008).

that the predicate maltrató a su hijo behaves like an atelic predicate, regardless of DOM, since it does not admit adverbials delimiting the event. Also, note that the example in (13a) would be ungrammatical without DOM. Hence, DOM cannot trigger a change in the reading of the verb if its occurrence is mandatory.

(13) Effect of DOM with an atelic verb on the aspect of the VP

a. Un escritor huido de la URSS maltrató a su hijo durante el último año de convivencia.

'A writer who fled the USSR abused his son during the last year of living together.'

(20 ${ }^{\text {th }}$ century, Manuel Vázquez Montalbán, La soledad del mánager)

b. * Un escritor huido de la URSS maltrató a su hijo en un mes/año.

'A writer who fled the USSR abused his son in one month/year.'

In addition, it is possible to find another argument against Torrego's second assumption in the example presented in (14). In this case, an activity verb such as arrastrar 'to drag', which is intrinsically atelic, should get a telic reading when its direct object has DOM. At first sight, this seems to be exactly the case, because no problem arises when the telicity test is applied, as shown in (14a). However, (14b) shows that telicity is not derived from DOM but from the PP indicating the goal of the event, i.e. hasta las gradas de la catedral 'to the cathedral steps'. If this goal PP disappears, as in (14b), the predicate stops behaving like a telic one and therefore does not admit a PP headed by en 'in'. 
(14) Effect of DOM with an atelic verb on the aspect of the VP

a. Arnal arrastró a su amigo hasta las gradas de la catedral (en dos minutos/ ${ }^{*}$ durante dos minutos).

'Arnal dragged his friend to the cathedral steps (in two minutes/ ${ }^{\star}$ for two minutes).'

(20 ${ }^{\text {th }}$ century, Wenceslao Fernández Flórez, Fantasmas)

b. Arnal arrastró a su amigo (*en dos minutos/durante dos minutos).

'Arnal dragged his friend (*in two minutes/for two minutes).'

With regard to the effect of DOM on atelic verbs, it might also be interesting to comment on the patterns of the verb rodear. As shown in (15), this verb has two readings in Spanish, one dynamic ('circle'/'go around') and one stative ('surround'), i.e. telic and atelic respectively.

(15) Aspectual readings of rodear ('go around'/'surround')

a. Los que del castillo baxaron rodearon al emperador por todas partes. (dynamic and telic)

'Those from the castle circled the emperor everywhere.'

(16 ${ }^{\text {th }}$ century, Sierra, Espejo de príncipes y caballeros, $2^{\underline{a}}$ parte)

b. En la sala, el grupo familiar rodeaba al patrón. (stative and atelic) 'In the living room, the family group was surrounding the boss.' (20 ${ }^{\text {th }}$ century, Valle-Inclán, Tirano Banderas)

Since rodear 'go around/surround' inherently offers two aspectual readings, the aspectual value of the VP will be given by factors different from the verbal head. This situation makes it easier to check not only which factors trigger a change in the lexical aspect, but also whether the occurrence of DOM itself triggers an aspectual change, as proposed in Torrego's second assumption (1999, 1788-1790). In this study, all instances of direct objects of this verb are $a$-marked and most of them are definite objects; therefore, without being able to disentangle definiteness from the rest of factors, it is difficult to determine the effect of secondary factors that affect the use of DOM. However, the example presented in (16) includes an indefinite object. Following Torrego, when the verb exhibits its telic meaning, the object has to be $a$-marked. This does not seem to be the case due to the sentence context (estaban sentadas diez esclavas blancas 'ten white slaves sat'), which indicates that it is a static situation. On the other hand, if the verb takes its atelic meaning, such as having an object with DOM, it should obtain a telic reading. However, this does not happen either, since the sentence context only allows for the stative reading, as we have just mentioned. 
(16) Effect of DOM on the aspect of the VP with rodear ('go around'/'surround') Una pradera en la que estaban sentadas diez esclavas blancas, rodeando a una joven.

'A meadow where ten white slaves sat, surrounding a young woman.' (20 ${ }^{\text {th }}$ century, Blasco Ibáñez, Traducción de las mil y una noches)

The reported instances question whether DOM functions as a trigger for a telic interpretation on atelic verbs. As demonstrated, atelic verbs keep their natural reading in spite of $a$-marking and, in case of presenting a telic interpretation, this does not seem to arise from DOM.

\section{Conclusions}

Drawing on diachronic data from a corpus-based study, this paper has contributed to the understanding of the factors that trigger Differential Object Marking (DOM) in Spanish. The aim of this study was to investigate the impact of telicity on DOM from a diachronic perspective and the results have revealed that, in contrast to other factors, such as affectedness (von Heusinger/Kaiser 2011; Romero Heredero in press) and agentivity (García García 2018), whose influence has been proven from a diachronic point of view, telicity has not produced any clear effect on the evolution of DOM.

As stated above, this work is the first empirical study that addresses the impact of telicity on DOM with human direct objects and, in addition, the first to address this verbal factor from a diachronic perspective.

The contribution of this study points to the conclusion that telicity can no longer be considered an independent factor that has a significant influence on the occurrence of DOM in Spanish, as it has been proposed by previous studies. Nevertheless, it remains open to the possibility that the slight variation found in the case of indefinite direct object NPs can be explained by the interaction of telicity with other factors such as affectedness and agentivity.

In recent years, it has been shown that the occurrence of DOM correlates not only to the highest degree of transitivity, but also to the lowest (cf. García García 2018 and Fábregas 2013 for discussion). Therefore, it has been suggested that the different factors configuring transitivity favour the use of $a$-marking, either by enhancing the transitivity of the clause, e.g. human affected direct objects, or by reducing it to the minimum, e.g. inanimate agentive direct objects. Following this approach, it has been assumed that telicity, like affectedness, increases the degree of transitivity and thus favours the use of DOM. However, according to the 
results obtained in this study, the idea arises that not all factors linked to transitivity somehow influence $a$-marking, and this is the case for telicity.

The analysis of the verbal factors involved in transitivity continues to be a promising field of study that needs further research to resolve the complex situation that the most recent studies reveal.

\section{Corpus}

$\mathrm{CDH}=$ Real Academia Española, Corpus del Diccionario histórico de la lengua española, 2013 [online], https://apps.rae.es/CNDHE [last access: 19.07.2021].

\section{Bibliography}

Barraza Carbajal, Georgina, Marcación preposicional de objeto directo inanimado, in: Company Company, Concepción/Moreno de Alba, José G. (edd.), Actas del VII Congreso Internacional de Historia de la Lengua Española. Mérida (Yucatán), 4-8 septiembre de 2006, Madrid, Arco, 2008, 341-352.

Company Company, Concepción, El avance diacrónico de la marcación prepositiva en objetos directos inanimados, in: Bernabé Pajares, Alberto, et al. (edd.), Presente y futuro de la lingüística en España. La Sociedad Lingüística, 30 años después. Actas del II Congreso de la Sociedad Española de Lingüística, vol. 2, Madrid, Consejo Superior de Investigaciones Científicas, 2002, 146-154.

Delbecque, Nicole, A construction grammar approach to transitivity in Spanish, in: Davidse, Kristin/Lamiroy, Béatrice (edd.), The nominative \& accusative and their counterparts, Amsterdam/Philadelphia, John Benjamins, 2002, 81-130.

Dowty, David, Word meaning and Montague grammar. The semantics of verbs and times in generative semantics and in Montague's PTQ, Dordrecht, Reidel, 1979.

Fábregas, Antonio, Differential Object Marking in Spanish. State of the art, Borealis 2:2 (2013), $1-80$.

Fernández Ramírez, Salvador, Gramática española, vol. 4, Madrid, Arco, 1986 [1951].

García García, Marco, Differentielle Objektmarkierung bei unbelebten Objekten im Spanischen, Berlin/Boston, de Gruyter, 2014.

García García, Marco, Nominal and verbal parameters in the diachrony of Differential Object Marking in Spanish, in: Seržant, Ilja A./Witzlack-Makarevich, Alena (edd.), Diachrony of Differential Argument Marking, Berlin, Language Science Press, 2018, 209-242.

Hopper, Paul J./Thompson, Sandra A., Transitivity in grammar and discourse, Language 56:2 (1980), 251-299.

Kabatek, Johannes, Wohin strebt die differentielle Objektmarkierung im Spanischen?, Romanistisches Jahrbuch 67:1 (2016), 211-239. 
Kiparsky, Paul, Partitive case and aspect, in: Butt, Miriam/Geuder, Wilhelm (edd.), The projection of arguments. Lexical and compositional factors, Stanford, CSLI, 1998, 265-308.

Krifka, Manfred, The origins of telicity, in: Rothstein, Susan (ed.), Events and grammar, Dordrecht, Springer, 1998, 197-235.

Laca, Brenda, El objeto directo. La marcación preposicional, in: Company Company, Concepción (ed.), Sintaxis histórica de la lengua española. Primera parte: La frase verbal, vol. 1, México DF, UNAM/Fondo de Cultura Económica, 2006, 423-475.

Leonetti, Manuel, Specificity and Differential Object Marking in Spanish, Catalan Journal of Linguistics 3:1 (2004), 75-114.

Lleal, Coloma (dir.), DiCCA XV - Diccionario del castellano del siglo XV en la Corona de Aragón, http://ghcl.ub.edu/diccaxv/ [last access: 12.02.2020].

Marín, Rafael, Una propuesta para el tratamiento de la información aspectual en HPSG, Procesamiento del lenguaje natural 24 (1999), 70-82.

Melis, Chantal, El objeto directo personal en "El Cantar de Mio Cid". Estudio sintácticopragmático, in: Pensado, Carmen (ed.), El complemento directo preposicional, Madrid, Visor, 1995, 133-163.

Octavio de Toledo y Huerta, Álvaro S., Aprovechamiento del CORDE para el estudio sintáctico del primer español moderno (ca. 1675-1825), in: Kabatek, Johannes (ed.), Lingüística de corpus y lingüística histórica iberorrománica, Berlin/Boston, de Gruyter, 2016, 57-89.

Ormazabal, Javier/Romero, Juan, Object clitics, agreement and dialectal variation, Probus 25:2 (2013), 301-344.

Real Academia Española, Diccionario de la lengua española, 23 ed. [online version 23.4] https://dle.rae.es [last access: 19.07.2021]

Richardson, Kylie, Case, in: Binnick, Robert I. (ed.), The Oxford handbook of tense and aspect, Oxford, Oxford University Press, 2012, 960-985.

Romero Heredero, Diego, Marcado diferencial de objeto y semántica verbal en español, Berlin/ Boston, de Gruyter, in press.

Tenny, Carol, Aspectual roles and the syntax-semantics interface, Dordrecht, Kluwer Academic, 1994.

Torrego, Esther, The dependencies of objects, Cambridge, Mass., MIT Press, 1998.

Torrego, Esther, El complemento directo preposicional, in: Bosque, Ignacio/Demonte, Violeta (edd.), Gramática descriptiva de la lengua española. Las construcciones sintácticas fundamentales. Relaciones temporales, aspectuales y modales, vol. 2, Madrid, Espasa Calpe, 1999, 1779-1805.

Vendler, Zeno, Verbs and times, Philosophical Review 66:2 (1956), 146-160.

Verkuyl, Henk J., On the compositional nature of the aspects, Dordrecht, Reidel, 1972.

von Heusinger, Klaus, Verbal semantics and the diachronic development of DOM in Spanish, Probus 20:1 (2008), 1-31.

von Heusinger, Klaus/Kaiser, Georg A., Affectedness and Differential Object Marking in Spanish, Morphology 21:3 (2011), 593-617.

von Heusinger, Klaus, The diachronic development of Differential Object Marking in Spanish ditransitive constructions, in: Seržant, Ilja A./Witzlack-Makarevich, Alena (edd.), Diachrony of Differential Argument Marking, Berlin, Language Science Press, 2018, 315-344.

von Heusinger, Klaus/García García, Marco/Montrul, Silvina, Microvariation of Differential Object Marking in Latin American Spanish on the basis of judgement tests, forthcoming. 


\section{Appendix: Verbs included in the study}

The following table contains all the verbs used for the analysis carried out in this work according to aspectual class. The subscript that follows some verbs distinguish their different meanings. These meanings have been checked using the $D L E$ and the DiCCA XV.

\begin{tabular}{|c|c|c|}
\hline STATE & & 449 \\
\hline abatir $_{2}$ & to depress & 1 \\
\hline admirar $_{1}$ & to admire & 36 \\
\hline $\operatorname{amar}_{1}$ & to love & 119 \\
\hline conocer $_{1}$ & to know & 107 \\
\hline identificar $_{2}$ & to compare & 12 \\
\hline preciar & to appreciate & 5 \\
\hline recordar $_{2}$ & to bear in mind & 23 \\
\hline recordar $_{3}$ & to remind & 14 \\
\hline rodear $_{1}$ & to surround & 38 \\
\hline tener $_{1}$ & to have & 94 \\
\hline ACTIVITY & & 1,218 \\
\hline acorrer & to help & 4 \\
\hline acribillar & to riddle & 10 \\
\hline admirar $_{2}$ & to amaze & 11 \\
\hline admirar $_{3}$ & to contemplate & 9 \\
\hline agitar & to shake & 6 \\
\hline agraviar & to offend & 4 \\
\hline alimentar & to feed & 2 \\
\hline $\operatorname{amar}_{2}$ & to make love & 3 \\
\hline amparar & to protect & 1 \\
\hline apalear & to beat & 43 \\
\hline apedrear & to stone & 29 \\
\hline apretar & to press & 38 \\
\hline arrastrar & to drag & 61 \\
\hline asediar & to besiege & 18 \\
\hline atender & to serve & 13 \\
\hline atormentar & to torment & 6 \\
\hline ayudar & to help & 5 \\
\hline azotar & to flog & 14 \\
\hline capitanear & to captain & 1 \\
\hline
\end{tabular}


(continued)

\begin{tabular}{|c|c|c|}
\hline \multicolumn{2}{|l|}{ STATE } & \multirow{2}{*}{$\frac{449}{23}$} \\
\hline castigar & to punish & \\
\hline catar $_{1}$ & to look & 4 \\
\hline cohechar & to force & 2 \\
\hline combatir & to combat & 48 \\
\hline consolar & to console & 6 \\
\hline contemplar & to contemplate & 11 \\
\hline contristar & to sadden & 2 \\
\hline criar & to raise & 79 \\
\hline empujar & to push & 47 \\
\hline enseñar & to educate & 5 \\
\hline evocar & to remember & 17 \\
\hline forzar & to force & 3 \\
\hline guardar & to protect & 2 \\
\hline guiar & to guide & 105 \\
\hline honrar & to honour & 15 \\
\hline hostigar & to harass & 1 \\
\hline humillar & to humiliate & 3 \\
\hline incitar & to encourage & 1 \\
\hline investigar & to investigate & 4 \\
\hline llevar & to take [sb] & 2 \\
\hline maltratar & to abuse & 122 \\
\hline martirizar & to torment & 4 \\
\hline menospreciar & to despise & 10 \\
\hline oír & to hear & 119 \\
\hline oprimir & to oppress & 30 \\
\hline pendrar & to hold & 3 \\
\hline percibir & to perceive & 2 \\
\hline proveer & to provide & 1 \\
\hline punir & to punish & 14 \\
\hline remolcar & to tow & 1 \\
\hline sacudir & to shake & 12 \\
\hline señorear & to domineer & 1 \\
\hline servir & to serve & 2 \\
\hline sitiar & to besiege & 4 \\
\hline transportar $_{1}$ & to transport & 37 \\
\hline ver & to see & 120 \\
\hline
\end{tabular}


(continued)

\begin{tabular}{|c|c|c|}
\hline \multicolumn{2}{|l|}{ STATE } & \multirow{2}{*}{$\begin{array}{r}449 \\
52\end{array}$} \\
\hline vigilar & to guard & \\
\hline zarandear & to shake & 26 \\
\hline ACCOMPLISHME & & 383 \\
\hline conocer $_{2}$ & to make love & 6 \\
\hline conocer $_{4}$ & to meet & 42 \\
\hline despedazar & to tear apart & 36 \\
\hline destrozar & to destroy & 30 \\
\hline identificar $_{3}$ & $\begin{array}{l}\text { to ask for the } \\
\text { documentation }\end{array}$ & 5 \\
\hline identificar $_{4}$ & $\begin{array}{l}\text { to prove the } \\
\text { identity }\end{array}$ & 5 \\
\hline neutralizar & to neutralise & 12 \\
\hline olvidar & to forget & 78 \\
\hline quemar & to burn & 79 \\
\hline recordar $_{1}$ & to recall & 15 \\
\hline recordar $_{4}$ & to remind & 1 \\
\hline rodear $_{2}$ & to circle & 15 \\
\hline traer & to bring & 60 \\
\hline transportar $_{2}$ & to transport & 1 \\
\hline ACHIEVEMENT & & 1,150 \\
\hline abatir $_{1}$ & to take down & 46 \\
\hline arrollar & to mow down & 44 \\
\hline catar $_{2}$ & to find & 1 \\
\hline clamar & to call & 16 \\
\hline conocer $_{3}$ & to recognise & 40 \\
\hline derribar & to knock down & 89 \\
\hline descartar & to reject & 8 \\
\hline descubrir $_{1}$ & to discover & 38 \\
\hline descubrir $_{2}$ & to uncover & 9 \\
\hline detectar & to detect & 9 \\
\hline eliminar & to eliminate & 31 \\
\hline encerrar & to lock [sb] up & 1 \\
\hline encontrar $_{1}$ & to find & 145 \\
\hline encontrar ${ }_{2}$ & to hit & 30 \\
\hline enviar & to send & 17 \\
\hline hallar & to find & 147 \\
\hline
\end{tabular}


(continued)

\begin{tabular}{|c|c|c|}
\hline STATE & & 449 \\
\hline herir & to wound & 2 \\
\hline identificar $_{1}$ & to recognise & 54 \\
\hline llamar & to call & 32 \\
\hline localizar & to locate & 62 \\
\hline matar & to kill & 111 \\
\hline mencionar & to mention & 36 \\
\hline nombrar & to name & 52 \\
\hline reconocer & to recognise & 1 \\
\hline tener $_{2}$ & to give birth & 5 \\
\hline vencer & to defeat & 122 \\
\hline TOTAL & & 3,200 \\
\hline
\end{tabular}

